\title{
Water erosion prediction project (WEPP) range- land hydrology component evaluation on a Texas range site
}

\author{
M. R. SAVABI, W. J. RAWLS AND R. W. KNIGHT
}

\begin{abstract}
Authors are hydrologist, USDA-ARS, National Soil Erosion Research Laboratory and Agricultural Engineering Dept., Purdue University, West Lafayette, Ind. 47907; hydrologist, USDA-ARS, Hydrology Laboratory, Beltsville, Md. 20705; hydrologist, Range Sciences Dept., Texas A\&M University, College Station.
\end{abstract}

\begin{abstract}
The USDA-Water Erosion Prediction Project (WEPP) is a new technology based on the fundamentals of hydrology, soil physics, plant science, hydraulics, and erosion mechanics. WEPP hydrology includes simulation of excess rainfall using the Green and Ampt infiltration equation, surface runoff routing, evapotranspiration, percolation, and surface drainage. Hydrometeorological, soil, topography, and vegetation data from a range in Texas were used to test the WEPP rangeland hydrology model. Measured surface runoff and root zone soil water content from the site were compared with the simulated results of the WEPP model. The results indicate that the WEPP model (version 93.0) is capable of simulating soil water content and storm runoff. The Nash and Sutcliffe coefficient, NSR, between measured and simulated root zone soil water content and storm runoff was .88 and .84 , respectively, for the bare ground plots. However, for the plots with herbaceous vegetation the discrepancy between model simulated storm runoff and soil water content was more than expected $(\mathrm{NSR}=.46$ and $\mathrm{NSR}=.53$, respectively).
\end{abstract}

Key Words: infiltration, runoff, modeling, simulation, soil water

The USDA-Water Erosion Prediction Project (WEPP) model was initiated in 1985. The WEPP model represents a new erosion prediction technology based on fundamentals of infiltration theory, soil physics, plant science, hydraulics, and erosion mechanics (Lane and Nearing 1989). The model provides several major advantages over existing erosion models; It reflects the effects of land-use changes due to agricultural, range, and forestry practices and it models spatial and temporal variability of the factors affecting the hillslope hydrologic and erosion regime. For instance, as vegetal cover, soil water content and soil bulk density changes during the simulation period, the key parameters for calculating storm runoff and erosion changes within the model.

The authors express sincere thanks to the personnel of Range Science Department, particularly Mr. Joe Dale Franklin, Texas A\&M University and the USDA- Natural Resources Conservation Service for providing the hydrologic data for model validation.

Manuscript accepted 8 Apr. 1995.
The WEPP model uses the Green and Ampt infiltration equation, which is physically based, to calculate infiltration and excess storm rainfall for unsteady rainfall ( $\mathrm{Chu}$ 1978). Excess rainfall is routed downslope to estimate the overland flow hydrograph using the kinematic wave method (Woolhiser and Liggett 1967, Eagleson 1970, Stone et al. 1992). Storm runoff is used in calculating rill erosion and flow transport capacity (Lane and Nearing 1989).

There have been several modeling approaches to simulate evapotranspiration and soil water content on a watershed (Ritchie 1972, Saxton et al. 1974, Wight and Neff 1983, and Shuttleworth and Wallace 1985). These models are varied in their complexity and accordingly incorporate various physical processes. However, each allows for the integration of physical and biological factors to simulate evapotranspiration and root zone soil water content over a variety of surface conditions. In the WEPP model, Ritchic's approach (Ritchie 1972) is selected because it uses readily available climate and vegetation data and has been tested over a range of conditions (Savabi et al. 1989, Arnold and Williams 1985, Pochop et al. 1985).

The objectives of this paper are to present the WEPP hydrology component for rangeland conditions and to evaluate the model using hydrological data from small rangeland plots with and without vegetation near Throckmorton, Texas.

\section{Model Description}

Only a brief description of the methodologies employed by the WEPP model to compute runoff, percolation, surface drainage, flow to drainage tiles or ditches, and fluctuation of the water table is provided in this article (Lane and Nearing 1989).

The WEPP hydrology (Fig. 1) maintains a continuous daily hillslope water balance by linking infiltration, evapotranspiration, percolation, and subsurface drainage flow using the water balance equation:

$$
\theta_{(d)}=\theta_{(d-1)}+p_{(d)}-\left[R O_{(d)}+D_{(d)}+Q_{(d)}+E T_{(d)}\right]
$$

where

$\theta=$ root zone water content, $\mathrm{cm}$

$\mathrm{d}=$ day of simulation 


$$
\begin{aligned}
& \mathrm{p}=\text { daily precipitation, } \mathrm{cm} \\
& \mathrm{RO}=\text { daily surface runoff, } \mathrm{cm} \\
& \mathrm{D}=\text { daily deep seepage, } \mathrm{cm} \\
& \mathrm{Q}=\text { daily subsurface drainage, } \mathrm{cm} \\
& \mathrm{ET}=\text { daily evapotranspiration, } \mathrm{cm}
\end{aligned}
$$

Actual plant transpiration and soil evaporation are calculated by the Ritchie's method (Ritchie 1972) as illustrated in Figure 1.

The plant growth model in WEPP uses EPIC (Williams et al. 1983) concepts of phenological crop development based on daily accumulated heat units, and a harvest index for partitioning grain yield. The Monteith approach (Monteith 1977) is used to determine potential biomass and water and temperature stress adjustments.

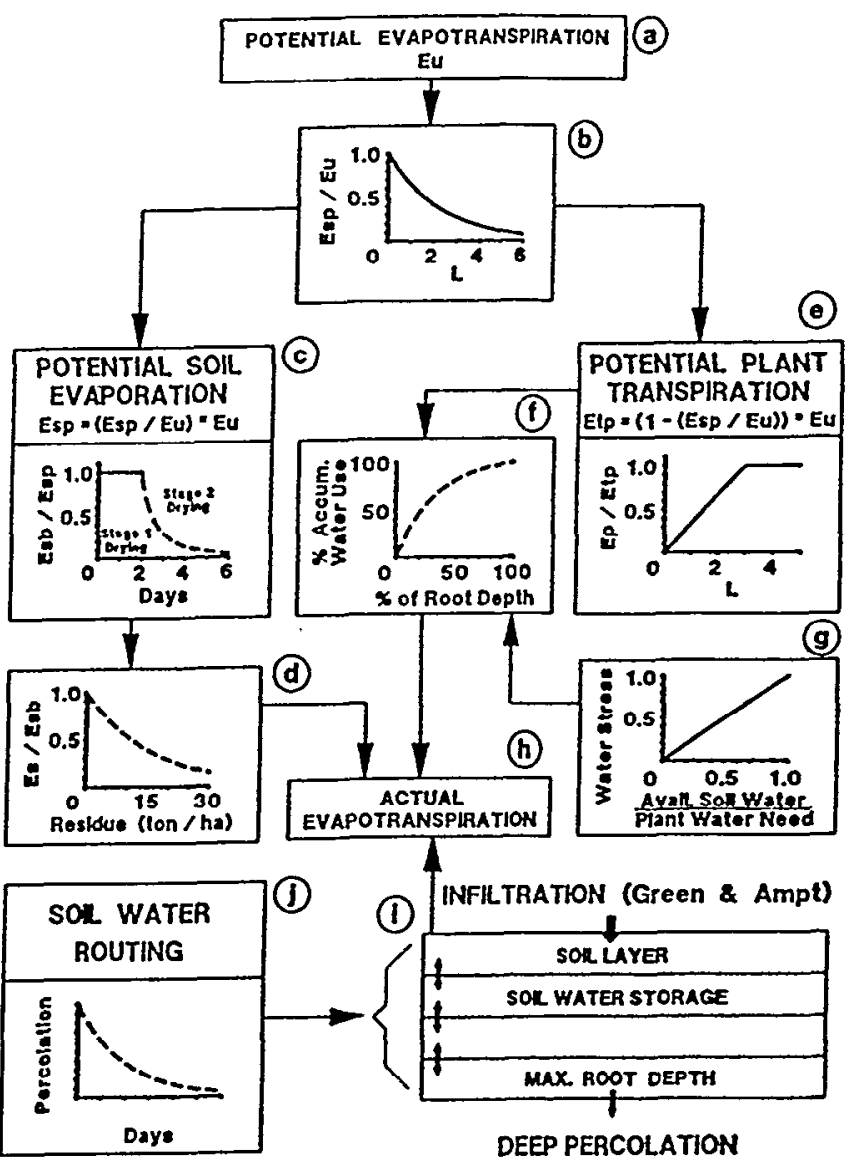

Fig. 1. Schematic computational sequence of the WEPP hydrology component, Eu is potential evaporation, Esp is potential soil evaporation, Esb is potential bare soil cvaporation, $L$ is leaf area index, Ep is potential plant transpiration, Es is potential soil evaporation for area covered by plant residue.

\section{Infiltration}

Excess rainfall is calculated as the difference between rainfall and infiltration. The infiltration equation used in the WEPP model is a solution of the single layer Green and Ampt equation (1911) for unsteady rainfall as presented by Chu (1978):

$$
f_{(t)}=K_{2}\left(1+\frac{N s}{F}\right)
$$

where

$$
\begin{aligned}
& \mathrm{f}=\text { infiltration rate, } \mathrm{cm}_{\text {hour }}{ }^{-1} \\
& \mathrm{~K}_{\mathrm{e}}=\text { effective hydraulic conductivity, } \mathrm{cm} \text { hour }{ }^{-1} \\
& \mathrm{t}=\text { time, hour } \\
& \mathrm{N}_{\mathrm{s}}=\text { effective matric potential, } \mathrm{cm} \\
& \mathrm{F}=\text { cumulative infiltration depth, } \mathrm{cm}
\end{aligned}
$$

The effective matric potential, $\mathrm{Ns}$, is given by:

$$
\mathrm{Ns}=\left(\eta_{\mathrm{e}}-\theta\right) \Psi
$$

where

$\eta_{c}=$ effective porosity of $0-20 \mathrm{~cm}$ of soil, $\mathrm{cm}^{3} \mathrm{~cm}^{-3}$

$\theta=$ initial volumetric soil water content of $0-20 \mathrm{~cm}$ of soil, $\mathrm{cm}^{3} \mathrm{~cm}^{-3}$

$\Psi=$ the average wetting front capillary potential, $\mathrm{cm}$

Rainfall excess is produced when the rainfall intensity exceeds the infiltration rate, $f_{t}$.

\section{Management Effect}

Saturated hydraulic conductivity (Ks) is an important parameter in determining storm excess rainfall and, therefore, runoff rate by the WEPP model. The effect of changes in vegetation cover on infiltration prediction is simulated in the WEPP model (version 93.0) by using the partial area contribution method. Equation 2 is solved separately for bare area, area with ground cover and for area under canopy. The saturated hydraulic conductivity for the soil matrix may be provided by the user or estimated within the model using soil information. The saturated hydraulic conductivity of the top soil layer is adjusted for each area to reflect the effect of soil surface conditions on the infiltration process. Since bare area on rangeland is exposed to raindrop impact, it is assumed to be crusted (Rawls et al. 1989). The saturated hydraulic conductivity is adjusted to simulate the effect of soil surface crust on infiltration. Crusted saturated hydraulic conductivity (Ksc) is calculated by the following equations:

$$
\begin{aligned}
& \mathrm{Ksc}=\mathrm{Ks}{ }^{*} \mathrm{Cr} \\
& \mathrm{Cr}=\frac{\mathrm{Dw}}{\frac{\mathrm{Dw}-\mathrm{Ct}}{\mathrm{Cs}}+\frac{\mathrm{Ct}}{\mathrm{Cq}}}
\end{aligned}
$$

where

$$
\begin{aligned}
& \mathrm{Cr}=\text { crust reduction factor, cm cm.1 } \\
& \mathrm{Dw}=\text { average wetting front depth, } \mathrm{cm} \\
& \mathrm{Ct}=\text { crust thickness, cm, assumed } 0.5 \mathrm{~cm} \\
& \mathrm{Cs}=\text { correction factor for partial saturation of the sub- } \\
& \mathrm{Cq}=\quad \begin{array}{l}
\text { crust soil }=0.736+0.19 \mathrm{Sa} \\
\mathrm{Sa}^{2} \mathrm{Ct}+315.1 \mathrm{Sa} \mathrm{Ct}^{2}
\end{array} \\
& \quad \text { (Brakensiek and Rawls (1983) } \\
& \mathrm{Sa}=\quad \text { fraction of sand in surface soil layer }
\end{aligned}
$$

Infiltration processes in the area under herbaccous vegetation and plant residue cover is assumed to be dominated by macropore flow (Rawls et al, 1989), therefore, Ks is adjusted for macroporosity effect by:

$$
\begin{aligned}
\mathrm{Ksm} & =\mathrm{Ks} * \eta_{\mathrm{m}} \\
\eta_{\mathrm{m}} & =\mathrm{e}^{6.10-10.3 \mathrm{Sa}-3.7 \mathrm{Cl}}
\end{aligned}
$$


where

$\mathrm{Ksm}=$ saturated hydraulic conductivity for area with macropores, $\mathrm{cm}$ hour ${ }^{-1}$

$\eta_{\mathrm{m}}=$ macroporosity factor, $\mathrm{cm} \mathrm{cm}^{-1}$

$\mathrm{Cl}=$ fraction of clay content in surface soil layer

The bare area under plant canopy is assumed crust free, and, therefore, a calculated and/or a user provided $\mathrm{K}_{\mathrm{s}}$ will be used for this area without adjustments. Excess rainfall (V) is determined for each area separately by subtracting infiltration rate $\left(f_{t}\right)$ from rainfall rate. The excess rainfall rate from the entire hillslope (Er) is determined by calculating the weighted average of excess rainfall from each area by this equation:

$$
\mathrm{Er}_{(\mathrm{t})}=\mathrm{VB}_{(\mathrm{t})}(\mathrm{b})+\mathrm{VG}_{(\mathrm{t})}(\mathrm{c})+\mathrm{VC}_{(\mathrm{t})}(\mathrm{p})
$$

where

$\mathrm{VB}=$ excess rainfall rate from bare area, $\mathrm{cm}$ hour ${ }^{-1}$

b = fraction of area without plant canopy or ground cover

VG = excess rainfall rate from herbaceous plant and residue covered area, $\mathrm{cm}$ hour ${ }^{-1}$

$c \quad=$ fraction of area with herbaceous plant and residue cover

$\mathrm{VC}=$ excess rainfall rate from bare area under shrub and tree canopy, $\mathrm{cm}$ hour ${ }^{-1}$

$\mathrm{p}=$ fraction of area without ground cover under canopy of shrubs and trees

Note that the total area contributing to excess storm runoff is assumed $100 \%(b+c+p=1)$.

\section{Surface Runoff}

Calculated rainfall excess (Er) is then routed downslope to estimate the overland flow hydrograph using the kinematic wave method. The kinematic wave equations for one-dimensional overland flow are derived by assuming that the land slope is equal to the friction slope (Stone et al. 1992). The Chezy equation is used in the WEPP model to describe flow characteristics. The Chezy friction coefficient, $\mathrm{C}$, is calculated for rill and interrill areas based on soil surface roughness and surface cover (Gilley et al. 1989).

\section{Surface Drainage}

In the WEPP model, surface drainage is characterized by the depressional storage. Depressional storage is directly related to the soil surface micro-relief feature and is generally enhanced by various soil mechanical practices, such as tillage. The method developed by Onstad (1984) is used in WEPP. Maximum depth of depressional storage $(\mathrm{cm})$ is calculated using the following equation:

$$
\mathrm{DS}=0.112 \mathrm{RR}+0.031 \mathrm{RR}^{2}-0.012 \mathrm{RR} * \mathrm{~S}
$$

where

$\mathrm{RR}=$ random roughness, $\mathrm{cm}$

$\mathrm{S} \quad=$ slope steepness, percent

Moore and Larson (1979), and Onstad (1984) reported that runoff from a hillslope begins before maximum storage, DS, is attained. The rainfall excess is required to completely satisfy the hillslope depressional storage, PR and, therefore, the entire hillslope contribution to runoff is calculated using the equation:

$$
P R=0.329 R R+0.073 R R^{2}-0.018 R R * S
$$

The amount of runoff leaving the hillslope, while depressional storage is filling, is determined using the equation:

$$
\begin{array}{ll}
\mathrm{Q}_{(\mathrm{t})}=\frac{\mathrm{DS}}{\mathrm{PR}} * \mathrm{Er}_{(\mathrm{t})} & \mathrm{FL}<\mathrm{DS} \\
\mathrm{Q}_{(\mathrm{t})}=\mathrm{Er}_{(\mathrm{t})} & \mathrm{FL} \geq \mathrm{DS}
\end{array}
$$

where

$\mathrm{Q}=$ runoff rate leaving the profile, $\mathrm{cm} \mathrm{h}^{-1}$

FL = accumulated amount of excess rainfall filling the depression storage, $\mathrm{cm}$, and $=\Sigma\left(Q_{(t)}-E_{(t)}\right)$

The volume of water filling the depressional storage for each rainfall event can be obtained by subtracting $Q$ from the appropriate excess rainfall rates. Excess rainfall filling the depression storage cannot exceed total depression storage, DS.

In WEPP soil water redistribution within the root zone is simulated using a storage routing technique (Savabi et al. 1989). Soil water in each layer and in excess of $-33 \mathrm{Kpa}$ is subjected to percolation to subsequent layer and lateral movement. The water that percolates below the root zone is called deep seepage and it is considered lost from the WEPP water balance. Soil water within the root zone is subjected to transpiration by plants and percolation. Soil water in the upper soil layer is subjected to evaporation (Savabi et al. 1989).

\section{Model Validation}

Hydrometeorological records along with soil, vegetation and topographic data from a rangeland site in Texas were used to evaluate the WEPP hydrology component.

\section{Site Description}

Field research was conducted by the Texas A\&M University Range Science Department on the Wagon Creek Spade Watershed Research area located in Throckmorton County, Texas. Climate is semi-arid continental with annual precipitation of about $646 \mathrm{~mm}$. The soil is fine, silty, mixed, thermic typic calciustolls (Nuvalde silty clay loam) that is deep, well-drained and slowly permeable (USSCS 1988). The vegetation of the site consists of grasses; sideoats grama (Bouteloua curtipendula (Michx.) Torr, Texas wintergrass (Stipa leucotricha Trin. and Rupr.), meadow dropseed (Sporobolos asper (Michx.) Kunth.) and Japanese brome (Bromus Japanicus Thumb.), Dominant forbs; heath aster (Aster ericoides and shrubs; honey mesquite (Prospis glandulosa Torr. var. glandulosa). Woody species on the site provide about $30 \%$ canopy cover.

\section{Treatments}

Nine mature mesquite trees of similar size werc selected as sites for placement of nine small catchments in July 1985. Trenches about $1 \mathrm{~m}$ beyond the canopy drip-line were cut around each tree to a depth of $2.5 \mathrm{~m}$ with plastic sheet to prevent subsurface lateral water movement. Fiberglass partitions were used as plot borders to prevent surface flow to or from the plots. The area of each plot ranged from 15 to $27 \mathrm{~m}^{2}$. A trough was attached to the downslope side of each plot to measure storm runoff and soil loss. Three vegetation treatments, bare ground, herbaceous vegetation, and mesquite with herbaceous vegetation were monitored. 
On the bare ground plots, all vegetation was removed; however, on the herbaceous plots only the mesquite tree was cut about 15 $\mathrm{cm}$ above the soil surface and the debries removed. Each treatment was replicated 3 times. Only the data from bare plots (bare) and herbaceous vegetation plots (natural) for the 1986 growing season were available and used in this study.

\section{Data Collection}

A Micrologger weather station was installed to monitor maximum, minimum and average air temperature, relative humidity, total solar radiation, total precipitation, storm duration and intensity. Detail soil profile descriptions were made on the site. Integrated soil samples were taken close to each plots and were analyzed for soil texture and soil organic matter content. In addition, soil bulk density was measured using the core method

Table 1. Soil surface characteristics of Wagon Creek Spade Watershed Research area located in Throckmorton County, Texas.

\begin{tabular}{lcccccccc}
\hline \hline Depth & $\mathrm{BD}^{1}$ & Clay & Sand & Rock & $\mathrm{OM}^{2}$ & $\mathrm{Ks}^{3}$ & $-33 \mathrm{Kpa}^{4}$ & $-1500 \mathrm{Kpa}^{5}$ \\
\hline $\mathrm{cm}$ & $\mathrm{g} / \mathrm{cm} 3$ & $\%$ & $\%$ & $\%$ & $\%$ & $\mathrm{~cm} / \mathrm{h}$ & $\%$ & $\%$
\end{tabular}

$\begin{array}{lllllllll}0-28 & 1.35 & 38 & 25 & 0.0 & 2.0 & .61 & 28 & 17\end{array}$

$\mathrm{BD}=$ soil bulk density, ${ }^{2} \mathrm{OM}=$ percent organic matter, ${ }^{3} \mathrm{Ks}=$ saturated hydraulic conductivity for soil, the value was obtained from eqaution 10 , water retained at $-33 \mathrm{Kpa}$, water retained at $-1500 \mathrm{Kpa}$.

(Table 1). Storm runoff and sediment leaving each plot were measured for each storm during the 1986 growing season. Runoff in depth unit (mm) was determined by dividing the total storm runoff (volume) by the area of each plot. Average storm runoff from each set of plots were used in this study because the variation in the factors influencing infiltration and soil water redistribution were not significantly different between the replication plots (Franklin 1987). Weekly volumetric soil water content of root zone $(0-2.4 \mathrm{~m})$ was monitored using 5 neutron moisture gauge access tubes installed in each plot.

\section{WEPP Input Data Files}

A brief description of WEPP input parameters is given here; the readers may refer to Lane and Nearing (1989) for more details. Climate input files inciude daily precipitation amount, duration of storm, maximum intensity of storm, time to maximum storm intensity, maximum and minimum temperatures, solar radiation, wind speed and dircction, and dew point temperature. Soil input files include such soil parameters as soil albedo, initial soil water content, soil textures, bulk density, saturated hydraulic conductivity, water retained at $-33 \mathrm{Kpa}$ and $-1500 \mathrm{Kpa}$, percent rocks, percent organic matter, and soil cation exchange capacity (CEC). Table 1 includes some soil surface characteristics of the site. The slope file includes physical features such as slope length, slope steepness and aspect. The management file requires land use to be identified by users. For rangeland application, information about range type, grazing intensity, grazing period and forage consumption is needed. The model simulates the effect of various management practices while simulating hydrological and erosion processes on the site.

The WEPP input files were made based on field observations. Rainfall, temperature, radiation, wind speed and direction, and dew point temperature were not available for the entire simula- tion period. Therefore, missing climate data were generated using the CLIGEN model (Nicks and Lane 1989). Based on storm characteristics (storm amount, duration, time to peak/total duration, and maximum intensity/average intensity of the given storm), the model assumes a triangle shape hyetograph. A dissagragation routine is used to calculate time-rainfall intensity from daily rainfall amounts (Lane and Nearing 1989). Saturated hydraulic conductivity of the soil was not avaliable for the site. Therefore, an equation developed by Rawls et al (1989) was used to estimate $\mathrm{Ks}$,

$$
\begin{aligned}
& K s=\left(\frac{\left(\emptyset_{\mathrm{e}} \theta_{\mathrm{r}}\right)^{3}}{\left(1-\emptyset_{\mathrm{e}}\right)^{2}}\right)\left(\frac{0.001 \rho}{\theta_{r}}\right)^{2} 0.0002 C^{2} \\
& \text { Where } \emptyset_{\mathrm{e}}=\text { effective porosity, } \mathrm{cm}^{3} \mathrm{~cm}^{-3} \\
& \theta=\text { residual water content, } \mathrm{cm}^{3} \mathrm{~cm}^{-3} \\
& \rho=\text { soil bulk density, } \mathrm{kg} \mathrm{m}^{-3} \\
& C \quad=-0.17+18.1 C l-69 S a^{2} C l^{2}-41.0 S a^{2} S i^{2} \\
& +1.18 S a^{2}\left(\frac{\rho}{1000}\right)^{2}+6.9 C l^{2}\left(\frac{\rho}{1000}\right)^{2}+49.0 S a^{2} C l \\
& -85.0 \mathrm{SiCl} \mathrm{C}^{2}
\end{aligned}
$$

Where, $\mathrm{Sa}, \mathrm{Cl}$, and $\mathrm{Si}$ are fractions of sand, silt, and clay in the soil.

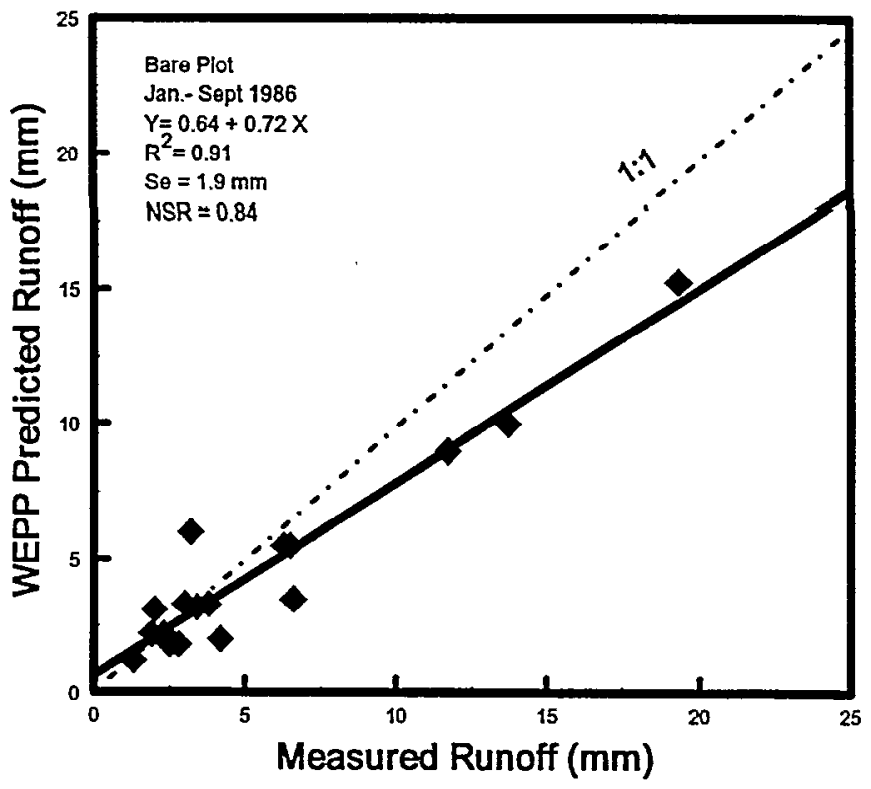

Fig. 2. Comparison of average measured and WEPP simulated storm runoff for bare plots. Measured runoff values are the average of the 3 replications (plots).

\section{Results and Discussions}

\section{Storm Runoff}

Comparison of mean measured and WEPP simulated storm runoff from the bare plots for January to September of 1986 is shown in Figure 2. The surface of bare plots was assumed crusted and, therefore, the saturated hydraulic conductivity used by the 
WEPP model to predict infiltration was adjusted using the crust reduction factor (Eq. 4). Regression analysis, coefficient of determination $\left(\mathrm{R}^{2}\right)$, standard error (Se), and the Nash-Sutcliffe coefficient, NSR (Nash and Sutcliffe 1970) were used to compare the observed and model simulated storm runoff and soil water content. Standard exror of residuals is given by the following:

$$
\mathrm{Se}=\left(\frac{1}{\mathrm{n}} \sum_{\mathrm{i}=1}^{\mathrm{n}}\left(\mathrm{M}_{\mathrm{i}}-\mathrm{P}_{\mathrm{i}}\right)^{2}\right)^{\frac{1}{2}}
$$

where

$M=$ measured value

$P=$ predicted value

$\mathbf{n}=$ number of events

$i=$ index of event number

A smaller Se indicates a better fit between observed and model simulated hydrologic values. The Se has the same units as the value which is being compared. The Nash-Sutcliffe coefficient is a dimensionless coefficient and has been recommended by the American Society for Civil Engineering task committee as a criteria to be used for comparison between observed and model simulated hydrologic variables (ASCE 1991):

$$
N S R=\frac{1-\sum_{i=1}^{n}\left(M_{i}-P_{i}\right)^{2}}{\sum_{i=1}^{n}\left(M_{i}-\bar{M}\right)^{2}}
$$

where

$$
\bar{M}=\text { average of measured values }
$$

The value of NSR approaches unity as the fit between observed and predicted values progressively improves. An NSR of 1.0 indicates a perfect fit between measured and predicted values.

The NSR of .84, $\mathrm{R}^{2}$ of .91 , and standard error of $1.94 \mathrm{~mm}$ indicates a good agreement between average measured and WEPP simulated storm runoff of bare plots. However, the model consistently under-predicts the storm runoff of greater than $10 \mathrm{~mm}$ (Fig. 2). The reason for this discrepancy may be due to several factors including over-predicting the $\mathrm{Ks}$ and/or the adjustment for the effect of crust. The mean measured storm runoff of natural plots was compared with WEPP simulated storm runoff (Fig 3 ). The NSR of .53 and $\mathrm{R}^{2}$ of .69 indicates that the discrepancy between average measured storm runoff and WEPP simulated storm runoff of natural plots is more than that of bare plots. The Se between average measured and predicted storm runoff is $.63 \mathrm{~mm}$. The reason for the smaller Se for natural plots than for bare plots (.63 vs. $1.94 \mathrm{~mm}$ ) is that the observed and simulated values are less than those in bare plots. For the natural plots, Ks may be adjusted for the effect of crusting and/or macroporosity depending on the surface area condition (Eq. 4-5). The reason for the discrepancy between average measured and WEPP simulated storm runoff on natural plots may be due to the Ks value for the soil matrix and/or adjustments of Ks for macroporosity and crusting effects. Work is underway to evaluate the Ks prediction and adjustments for various soil surface conditions on rangelands. However, comparison of our results with the earlier Green and Ampt infiltration application on rangeland by DeVaurs and Gifford (1986), Hutton and Gifford (1988) indicates that the adjustments of Ks for macroporosity and crust effects on infiltration had improved the applicability of the Green and Ampt infil-

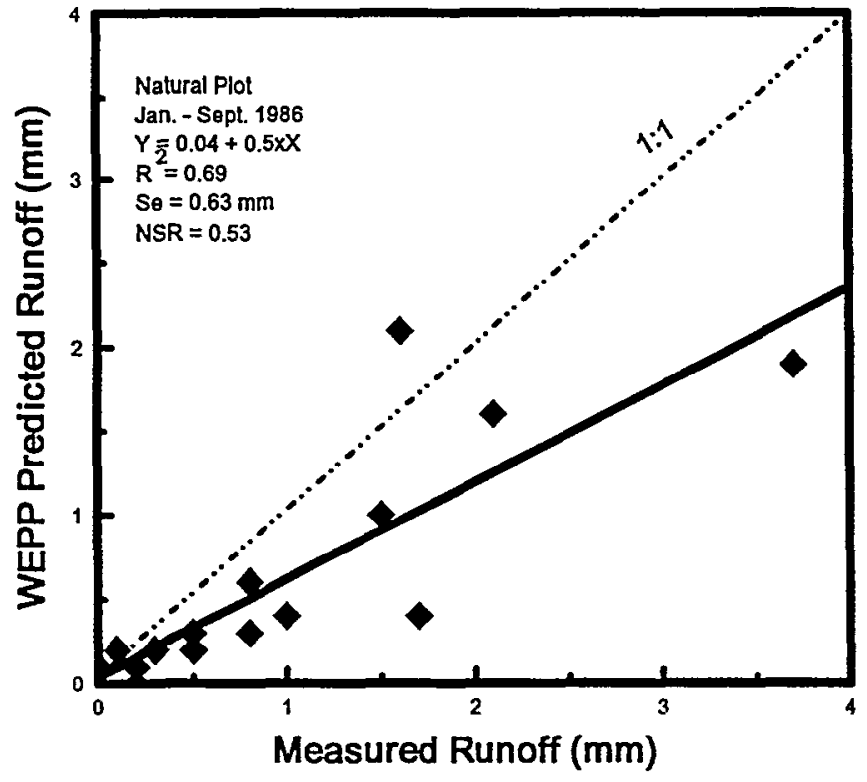

Fig. 3. Comparison of average measured and WEPP simulated storm runoff for natural plots. Measured runoff values are the average of the 3 replications (plots).

tration equation to rangelands. The same findings were reported by Savabi et al. (1990).

\section{Root Zone Soil Water Content}

It is important that the hydrologic models accurately simulate storm runoff and root zone soil water content. The latter is important in plant growth modeling and antecedent soil moisture for infiltration calculations. Figures 4 and 5 show the averages observed and WEPP model simulated soil water contents $(0-2.4 \mathrm{~m})$ of bare and natural plots for the 1986 growing season. As was the case for storm runoff, WEPP simulated the soil water content of bare plots better than it simulated the soil water content of natural plots (Fig. 4-5). Better prediction of soil water content for bare plots (Fig. 4) should be the result of closer agree-

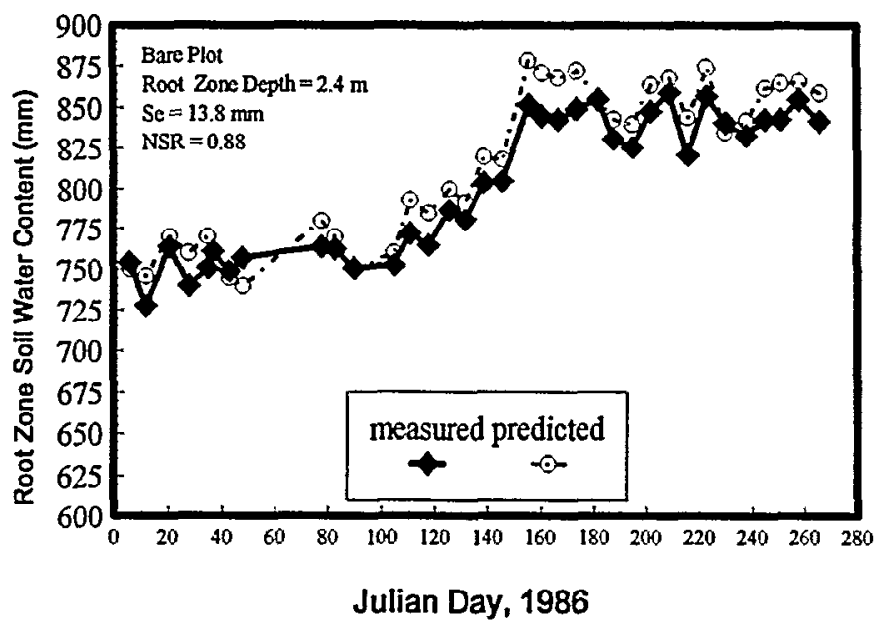

Fig. 4. Comparison of measured and WEPP simulated root zone soil water content for bare plots. Measured runoff values are the average of the 3 replications (plots). 


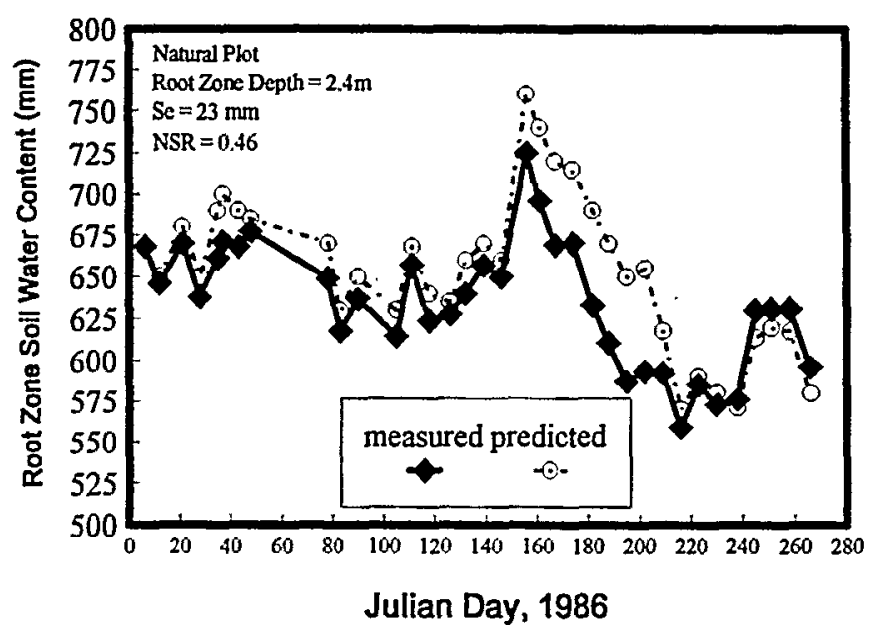

Fig. 5. Comparison of measured and WEPP simulated root zone soil water content for natural plots. Measured runoff values are the average of the 3 replications (plots).

ment between the bare plots measured and predicted storm runoff. Hence, the model links the infiltration calculation with evapotranspiration and soil water redistribution to maintain daily soil water balance.

\section{Summary and Conclusions}

The product of the USDA-Water Erosion Prediction Project (WEPP) is a computer model to predict water-induced soil erosion, storm runoff, root zone soil water, evapotranspiration, plant growth and snow melt on cropland, rangeland and forestland watersheds (Lane and Nearing 1989). The WEPP model provides several major advantages over existing hydrologic models; namely, it reflects the effects of land-use changes due to agricultural, range and forestry practices, and it models spatial and temporal variability of the factors affecting the surface and subsurface water quality and quantity along a single hillslope or over a small watershed. The major application of the WEPP model is to assess the hydrological condition and the erosion potential of the existing land practice and/or for a proposed set of alternative land management practices. Different watershed management practices may be evaluated by using the model to predict the effect of a given practice on surface runoff and sediment yield from fields to prevent excessive degradation of off-site water quality and inland reservoirs.

The hydrology component of WEPP utilizes the PenmanMontieth equation to predict daily evapotranspiration losses. The model links the Green and Ampt infiltration equation with the soil water balance routine in order to simulate daily root zone soil water content. Range management practices which affect vegetation cover will affect the infiltration prediction by the WEPP model. The infiltration equation predicts the water intake rate of bare area, ground covered area and bare area under canopy separately. The excess rainfall on a hillslope is calculated by obtaining the weighted average of excess rainfall from the three areas. Calculated rainfall excess is then routed downslope to estimate the overland flow hydrograph using the kinematics wave method. The WEPP hydrology model (version 93.0) was tested on bare and vegetative plots in Texas. Considering the limitation of available hydrometerological and soil-water data, the results indicate that the WEPP hydrology model can be used to simulate the effect of temporal and spatial vegetative cover on storm runoff under the given conditions. However, further evaluation of the WEPP hydrology model on different range types with different soils, climate and vegetation that are subject to various management practices are needed before WEPP rangeland implementation takes place. Work is under way to provide guidelines for using infiltration parameters for major range types under different range management practices.

\section{References}

American Society of Civil Engineering. 1991. Evaluation Criteria for Watershed Models, ASCE Task Committee, Proc. of ASCE-Watershed Manage. Symposium. July 1991, Durango, Colo.

Arnold, J. G., and J. R. Williams. 1985. Evapotranspiration in a basin scale hydrologic model. In: Advances in Evapotranspiration, proceedings of the national conference on advances in Evapotranspiration, ASAE, St. Joseph, Mo. 49085, pp. 405-413.

Brakensiek, D. L., and W.J. Rawls. 1983. Agricultural Management effects on soil water processes. Part II. Green and Ampt Parameters for crusting soils. Trans. ASAE 26:1753-1757.

Chu, S. T. 1978, Infiltration during unsteady rain. Water Resour. Res. 14: $461-466$.

DeVaurs, M. and G. F. Gifford. 1986. Applicability of the Green and Ampt infiltration equation to rangelands, Water Resour. Bull. 22:19-28.

Eagleson, P. S. 1970. Dynamic Hydrology, McGraw-Hill Book Co. New York, N.Y., 462 pp.

Franklin J. D. 1987. Hydrologic Aspect of Grass Dominated and Honey Mesquite Dominated Areas on the Rolling Plains of Texas. Master Thesis, Texas A\&M University, Range Science Dept. College Station, Texas. pp 150.

Gilley, J. E., S. C. Finkner, M. A. Nearing, and L. J. Lane. 1989. Hydraulics of overland flow, In: USDA-Water Erosion Prediction Project: Hillslope Profile Model Doc., NSERL Rep. No. 2, Chapter 9.

Green, W. H. and G. A. Ampt. 1911. Studies in Soil Physics, I. The flow of water through soils. J. Agr. Sci. 4:1-24.

Hutton, N. C. and G. F. Gifford. 1988. Using the Green and Ampt infiltration equation on native and plowed rangeland soils. J. Range Manage. 41:159-161.

Lane, L. J. and M. A. Nearing (eds.). 1989. USDA-Water Erosion Prediction Project: Hillslope Profile Model Documentation. NSERL Rep. No. 2.

Montieth, J. L.. 1977. Climate and the efficiency of crop production in Britain. Phil. Trans. Res. Soc., London B. 281: pp. 277-329.

Moore, I. D. and C. L. Larson. 1979. Estimating Microrelief Surface Storage from Point Data. Trans. ASAE 20:1073-1077, 1079.

Nash, J. E. and J. E. Sutcliffe, 1970. River Flow Forecasting Through Conceptual Models, part 1-A discussion of principles. J. of Hydrology, 10:282-290.

Nicks, A. D and L. J.. Lane, 1989. Weather generator. In: L. J. Lane and M. A. Nearing (Editor). USDA- Water Erosion Prediction Project: Profile Model Documentation. NSERL Rep. No. 2 USDA- ARSNational Soil Erosion Research Lab., W. Lafayette, Ind. 49709. Chapter 2.

Onstad, C.A. 1984. Depressional Storage on Tilled Soil Surfaces. Trans. ASAE 27:729-732.

Pochop, L. O., F. M. Smith and R. E. Smith. 1985. Evapotranspiration Estimation for the PAWNEE Grasslands, In: Advances in Evapotranspiration, Proceedings of the National Conference on Advances in Evapotranspiration, ASAE publication 14-85, St. Joseph, Mo. 49085, pp. 262-267.

Rawls, W. J., D. L. Brakensiek and R. Savabi. 1989. Infiltration parameters for rangeland soils. J. Range Manage. 42:139-142. 
Ritchie, J. T., 1972. A model for predicting evaporation from a row crop with incomplete cover. Water Res. Res. 8:1204-1213.

Savabi, M. R., E.T. Engman, W. P. Kustas, W. J. Rawls, and E.T. Kanemasu. 1989. Evaluation of WEPP Water Balance Model for Watershed 1D in Konza Prairie, Kansas. In: Proceedings of the 19th Conference, Agricultural and Forest Meteorology, March 7-10, 1989, Charleston, S.C., pp. 147-150.

Savabi, M. R., W. J. Rawls, and J. R. Simanton. 1990. Rangeland Evaluation of WEPP Hydrology. In: Proceeding of IR Conference Watershed Manage./IR Div./ASAE, Durango, Colo., July 1990, pp 77-87.

Saxton, K. E., H. P. Johnson and R.W. Show. 1974. Modeling evapotranspiration and soil moisture. Trans. ASAE 17:673-677.

Shuttleworth, W. J. and J. S. Wallace, 1985. Evapotranspiration from sparse crops - an energy combination theory. Quart. J. Roy. Met. Soc. 111:839-855.
Stone, J. J., L. J. Lane and E. D. Shirley. 1992. Infiltration and Runoff Simulation on a Plane. Trans. ASAE, 35:161-170.

United States Soil Conservation Service (USSCS). 1988. Soil Survey of Concho County, Texas. USDA, Washington, D.C.

Wight, J. R. and E. L. Neff. 1983. Soil-Vegetation-hydrology studies, Vol. II. A user manual for EHRYM: The Ekalaka Rangeland Hydrology and Yield Model. USDA-ARS, Boise, Ida.

Williams, J. R., P. T. Dyke, and C.A. Jones. 1983. EPIC-A model for assessing the effects of erosion on soil productivity. Proc. Third Int. Conf. on State-of -the-Art in Ecol. Modeling, Colorado State Univ., May 24-28, 1982, pp. 553-572.

Woolhiser, D. A., and J. A. Liggett. 1967. Unsteady, One Dimensional flow over a plane-the rising hydrograph, Water Res. Res. 3: 753-771. 